STATE OF ILLINOIS

HENRY HORNER, Goternor

DEPARTMENT OF REGISTRATION AND EDUCATION

DIVISION OF THE

NATURAI, HISTORY SURVEY

THEODORE H. FRISON, Chief

Article 2

\title{
Responses of
}

\section{the Large-mouth Black Bass to Colors}

FRANK A. BROWN, JR.

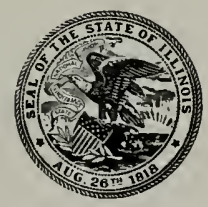

PRINTED BY AUTHORITY OF THE STATE OF ILLINOIS

URBANA, IJLINOIS

$$
\text { May } 1937
$$




\section{STATE OF ILLINOIS \\ Henry Horner, Governor \\ DEPARTMENT OF REGISTRATION AND EDUCATION \\ John J. Hallihan, Director}

\section{BOARD OF NATURAL RESOURCES AND CONSERVATION John J. Hallihan, Chairman}

William Trelease, D.Sc., LL.D., Biology Henry C. Cowles, Ph.D., D.Sc., Forestry John W. Alvord, C.E., Engineering

William A. Noyes, Ph.D., LL.D., Chem.D., D.Sc., Chemistry

Arthur Cutts Willard, D.Eng., LL.D., President of the University of Illinois

\section{NATURAL IISTORY SURVEY DIVISION \\ URBANA, ILLINOIS \\ Scientific and Technical Staff \\ Theodore H. Frison, Ph.D., Chief}

\section{SECTION OF ECONOMIC ENTOMOLOGY}

W. P. Flint, B.S., Chief Entomologist

C. C. Compton, M.S., Associate Entomologist

M. D. Farrar, Ph.D., Research Entomologist

S. C. Chanderer, B.S., Southern Field Entomologist

J. H. Bigger, B.S., Central Field Entomologist

L. H. Shropshire, M.S., Northern Field Entomologist

W. E. MCC AULEY, M.S., Assistant Entomologist

C. W. Kearns, Ph.D., Research Fellow in Entomology

J.F. Alsterlund, M.S., Research Fellow in Entomology

Dwight Powel., M.S., Research Fellow in Entomology

\section{SECTION OF APPLIED BOTANY ANI \\ PLANT PATHOLOGY}

L. R. TEHON, Ph.D., Botanist

J. C. CARter, Ph.D., Assistant Botanist

G. H. BoEwE, M.S., Field Botanist

\section{SECTION OF FORESTRY}

James E. Davis, M.F., Extension For. ester

\section{SECTION OF AQUATIC BIOLOGY}

Davio H. Thompson, Ph.D., Zoologist

F. D. Hunt, Field Naturalist

D. F. Hansen, A.M., Assistant Zoologist

D. J. O'Donnelt, M.S., Assistant Zoologist

\section{SECTION OF INSECT SURVEY}

H. H. Ross, Ph.D., Systematic Entomologist

Carl O. Mohr, Ph.D., Associate Entomologist, Artist

B. D. Burks, M.A., Assistant Entomologist

\section{SECTION OF GAME RESEARCH AND
MANAGEMENT}

R. E. YEATter, Ph.D., Game Specialist W. H. LeIGH, M.A., Assistant Zoologist

\section{SECtion of publications}

Carroll Chouinaro, M.A., Editor 


\section{Contents}

Problem of Color Vision in Fishes.................... 33

Survey of literature. Significance of determining color vision in black bass. Acknowledgments.

Materials for the Experiments.................. 35 Fish. Apparatus. Colored pipettes. Black, gray and white pipettes. Color rods.

Training and Responses of Large-mouth Black Bass. . . . . . . . . 37

Method. Reactions of untrained fish to colors and grays. Training to each of four colors. Responses of fish trained to four colors. Training to each of four colors plus tints. Responses of fish trained to four colors plus tints.

Interpretation of the Responses . . . . . . . . . . . 50

Summary . . . . . . . . . 53

Bibliography ..... . . . . . . . . . . . . . 54 


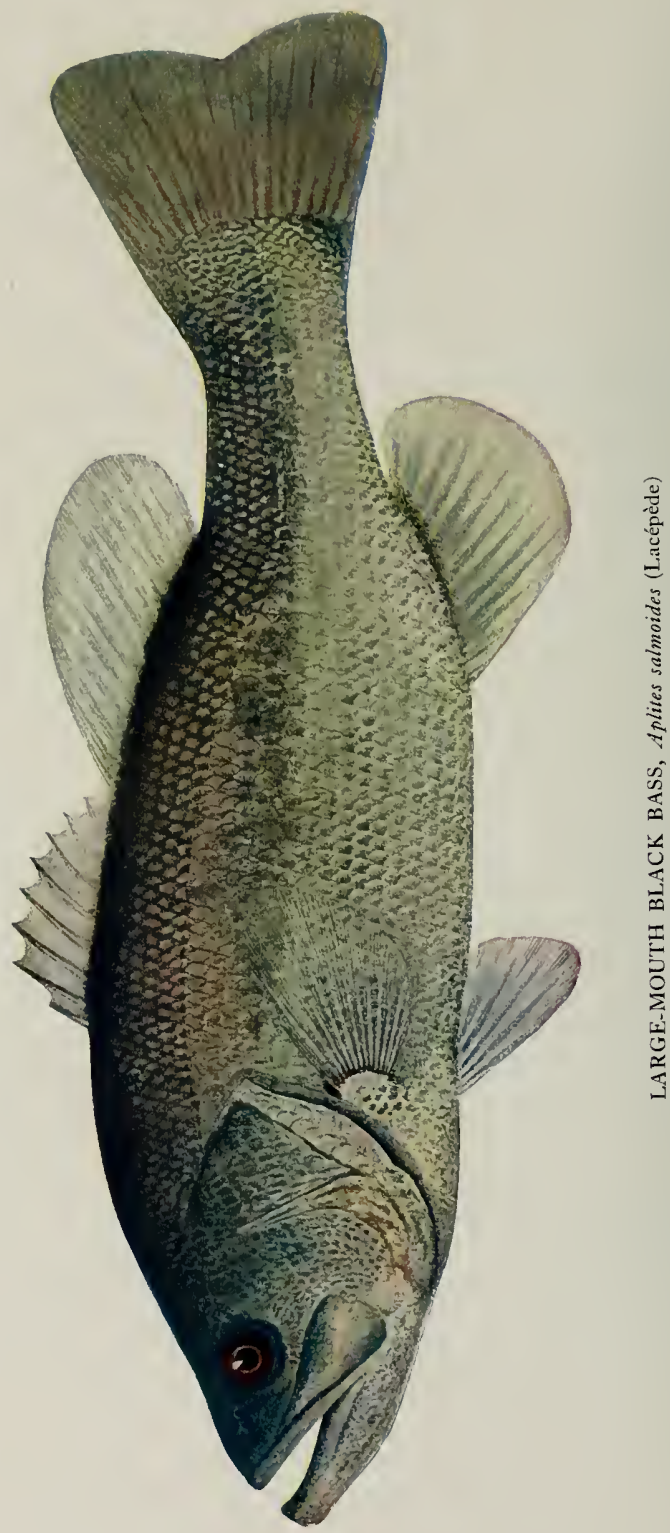




\title{
Responses of \\ the Large-mouth Black Bass' to Colors
}

\author{
FRANK A. BROWN, JR.2
}

\section{PROBLEM OF COLOR VISION IN FISHES}

B ECAUSE an excellent review of color vision in fishes has been written recently by Warner (1931), a detailed historical introduction here is considered unnecessary. A brief statement of the work done in this field, however, is included to permit a clearer understanding of the results and interpretations that are to be found in this report.

\section{Survey of Literature}

The problem of color vision in fishes was one which rather early attracted the attention of zoologists. Four general modes of attack upon this problem have been used, that of colored light preference, that of choice of variously colored foods, that of the responses of the integumentary pigmentary system to colored backgrounds, and finally, that of training fishes to discriminate anong colors through the formation of associations. These methods are listed in the order in which they have received the most of their popularity, the oldest experiments being almost exclusively of the preference type while the latest ones are almost always of the association type.

Thus far nearly all zoologists are agreed that if a fish responds in a specific manner to light of a particular color in contrast to light of all other colors and intensities of white, i.e., if it can be established that the difference of be-

1 Aplites salmoides (Lacépède).

2Assistant zoologist, IlLinois NATURal History Survey, July-August 1935. havior is in response to wave length and not intensity, then the fish may be spoken of as having color vision for that particular wave length of light. Those few who are not contented with such a broad interpretation of color vision must certainly be content with the results derived from the formation of association between colors and foods.

It is generally accepted that the form and function of animals are primarily concerned with feeding, protection of self, and reproduction. 'The methods of training fishes used by most investigators utilize the first, second, or both of these. Thus we may reason that any differential responses to wave lengths of light which involve such fundamental factors as these, together with modification of behavior in the face of a new situation, will concern the most highly evolved functional regions of the central nervous system. Even here, however, we need not consider such speculative aspects as the degree of consciousness of the fish with respect to the stimulus quality, or whether light of any particular wave length produces the same sensation in a fish as in man.

Graber (1884, 1885), utilizing the phototactic responses of the fishes, determined that Corbitus barbatula, Alburnus spectabilis, Gasterosteus spinchia, and Syngnathus acus selected areas illuminated by light of one color in preference to areas lighted by another color. Bauer (1910, 1911) similarly used a 
preference method with the fishes Charaz puntazzo, Atherina hepsetus, Box salpa and Mugil sp., and came to the conclusion that these fishes likewise had a color vision. On the other hand, Hess (1910, 1911, 1913, 1914) published a series of papers upon color vision in a number of kinds of young fishes. $\mathrm{He}$ too used chiefly the preference method. His interpretation of his experiments indicated that fish vision was approximately that of a color-blind man, and that the apparent differences in response to different colors were based solely upon differences in intensities. Hess severely criticised the work of Graber and Bauer in not having eliminated the possibility that the effects they obtained were due to brightnesses.

Upon similar grounds Hess discredited as evidence establishing color vision the observations of Zolotnitsky (1901) and Reighard (1908). Zolotnitsky had found that fish that had been fed for some time upon red chironomid larvae would snap only at red pieces of yarn when a number of variously colored bits of yarn were attached to the outside of the glass container. Reighard (1908) had noted that Lutianus griseus selected baits of one color in preference to baits of another.

Sumner (1911) and Mast (1916), working upon the adaptations of flatfishes to colored backgrounds, arrived at the conclusion that their color vision was much like that of man. Haempel \& Kolmer (1914), experimenting with Cottus gobio and Phoxinus laevis, found that these fishes became reddish when upon a red background. Connolly (1925) showed that Fundulus heteroclitus would modify its pigmentary system in a different fashion in red and yellow lights than in blue light. That color change in fishes in response to colored backgrounds proves color vision to exist has been seriously questioned by Schnurmann (1920). He shows that the color adaptations in the minnow Phoxinus appear to be the reactions of a color-blind fish with approximately the characteristics of vision of a color-blind man looking through a yellow-tinted screen. A screen of this sort would absorb the short wave lengths much more than the long ones and thereby the differential response may result from intensity.

A rather conclusive work upon the color vision of fishes was performed by von Frisch (1913) who trained Phoxinus laevis to respond positively to a particular color and then had the fish select that color out of a long series of grays. He also demonstrated that red, yellow and purple-red were much alike to the fish. Green and blue were distinguishable from one another and from red and yellow. Burkamp (1923), using in principle the same kind of technic, arrived at essentially similar conclusions for Phoxinus laevis, Rhodeus amarus, Idus melanotus and Tinca vulgaris. Both von Frisch and Burkamp controlled the intensities of their colors principally in using a confusing series of grays. The latter worker also used colors diluted with black and white.

Washburn \& Bentley (1906) trained Semotilus atromaculatus to accept food from a red pair of forceps and to refuse it when offered from green. An attempt was made to control the intensity by reversing the order of brightness of the colors as they appeared to the human eye. White (1919) and Hineline (1927), employing color filters, showed that Umbra limi and Eucalia appear to distinguish between all colors with the exception of the combination green and blue. The latter work has also been criticized in that it has not sufficient control of the intensity factor.

Reeves (1919) was the only one to equalize two colors in the brightnesses that they appeared to the fishes themselves and then to have the fishes distinguish between them. Miss Reeves has demonstrated quite conclusively that Semotilus atromaculatus and Eupomotis gibbosus distinguish red from blue by virtue of the color values.

Schiemenz (1924) used a method in which he trained Phoxinus to respond positively to a white enameled stick upon which was shone light of a particular wave length and to refuse to respond to other colors. These colors were obtained by screening off small portions of a spectrum obtained with a prism. The intensity factor was controlled by varying the variously colored 
lights through a broad range of intensities. Wolff (1926) permitted trained fish to select their training color from a series of spectral colors presented simultaneously. 'These two researches have demonstrated quite conclusively that Phoxinus laevis is able to distinguish among about 20 colors of the visible spectrum and ultraviolet by virtue of color as opposed to brightness. These last two are perhaps the most complete experiments which have been carried out in the field of color vision of fishes.

A critical summary of the field now indicates that the minnow Phoxinus laevis is able to distinguish about 20 colors from one another by virtue of the wave length of the light. Furthermore, it appears to be proved that Semotilus atromaculatus and Eupomotis gibbosus are able to distinguish red from blue solely by differential effects of the colors as distinct from intensity. Beyond these statements all we can say is that it is quite probable that about 15 or 20 more genera of fishes also have a kind of color vision although this has not been decisively proved.

\section{Significance of Determining Color Vision in Black Bass}

In view of the small amount of conclusive data upon the color vision of fishes and the fact that the best of what there is has been for all practical purposes confined to few genera of fishes, it was believed profitable to investigate the color vision of the large-mouth black bass, Aplites salmoides (Lacépède). The fact that there is a color vision in some fishes does not preclude the possibility of some other fishes being color blind or having modified color vision.

In addition to the purely scientific outlook upon this problem, there are some economic aspects to the study of this particular fish. Thousands of dollars are spent annually for the purchase of highly colored bass lures by sportsmen. Bass in some regions are believed to prefer one color or combination and those of other regions, others. Furthermore, there is often voiced the belief that at different times of day or in different weathers there are changes in the choice of colors by this fish. Thus this work has a double interest.

\section{Acknowledgments}

This investigation was carried out during the summer of 1935 . I should like to take this opportunity to acknowledge my indebtedness to Dr. David H. Thompson, of the Illinois State Natural History Survey, at whose suggestion this work was undertaken and who was extremely generous with constructive criticism throughout the course of the work. Furthermore, I wish to express my gratitude to Francis $\mathrm{X}$. Lueth, student assistant with the Survey, who served as an invaluable aid, and to O. C. McMillin, who kindly constructed certain pieces of the apparratus.

\section{MATERIALS FOR THE EXPERIMENTS}

\section{Fish}

All the fish used in the following experiments were large-mouth black bass which were caught in Crystal lake, Urbana, IIl. One lot of animals was taken on July 5 and the second lot on July 23. The fish varied in length from 2.5 to $4.8 \mathrm{~cm}$. at the time they were caught. Upon being brought into the laboratory the fish were first allowed to remain in large aquaria for a day or more in order to accustom them to the laboratory temperatures and water supply. Thereafter they were placed in individual white enameled basins, where they remained for the rest of the experimentation.

\section{Apparatus}

Twelve white enameled basins were lined up along one side of a room. There were no windows along this side and as a result the illumination was independent of the changing sky light to a considerable degree. Never at any time did the fish receive direct sunlight. Throughout the actual experimentation the fish were lighted by a number of incandescent lamps in such a way that the dishes were all quite uniformly illuminated to the extent of 12 to 20 foot-candles, depending upon the amount of daylight entering through the single window of the room.

The water in the basins was maintained at a depth of $2.5 \mathrm{~cm}$. and was changed every second day. 
The circular bottoms of the pans were $15 \mathrm{~cm}$. in diameter. These bottoms were marked off in arcs of circles differing 1 cm. in radius from one another and all having a common center at a point upon the circumference of the bottom of the pan nearest the observer, fig. 1 . The marking of the bottoms of the pans in this manner enabled an observer quite accurately to record the distance of the bass at any given moment from the given point upon the periphery of the dish where training pipettes were to be presented and the fish fed or shocked in association.

For shocking the fish, each dish was provided with a pair of fixed copper electrodes $12 \mathrm{~cm}$. apart, dipping into the water at the edge of the pan approximately equidistant on either side of the common center of the arcs of the circles, fig. 1, EE. A 12 -way switch permitted the experimenter to shock any fish without disturbing the others. Thus, everything in the pans was constant

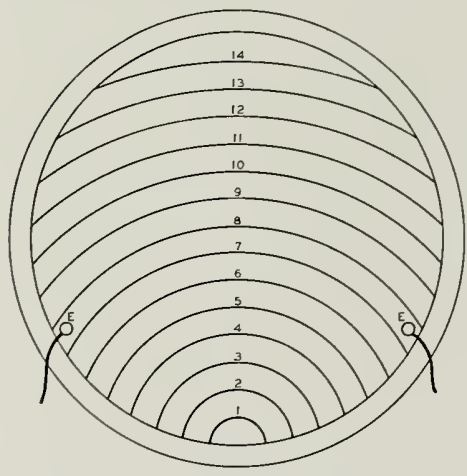

Fig. 1.-Diagram of the markings upon the bottom of a training basin, and the position of the electrodes, EE.

except for the pipettes, which were presented at a given spot from time to time.

The electric current for the shock was furnished by two dry-cell batteries and a Harvard inductorium with the secondary coil set at about 7 upon the scale of the instrument. A button switch was attached to an extension cord in order that the observer could conveniently carry out the whole training procedure.

\section{Colored Pipettes}

It was found that an ordinary pipette (medicine dropper) covered neatly with white adhesive tape could be readily

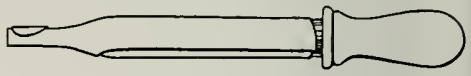

Fig. 2.-Training pipette, showing the manner in which the white adhesive tape was applied.

colored by wax crayons or water colors and at the same time act as an opaque container in which the Daphnia or mosquito larvae which were used as food material could be held concealed until the time for feeding arrived.

The adhesive tape was applied to all the pipettes as shown in fig. 2. This was done in such a way as to cover the whole of the glass even to the tip.

The colors involved in the experiment were standard according to Ridgway (1912). Wax crayon was used to color the tape on the pipettes for the following:

\section{Rose red \\ Scarlet \\ Flame scarlet \\ Lemon yellow \\ Scheele's green \\ Meadow green \\ Helvetia blue \\ Seal brown}

The following could be obtained only by using water colors:
Orange rufous
Analine yellow
Calliste green
Thulite pink
Pale greenish yellow
Pale turquoise green
Light Columbia blue

\section{Black, White and Gray Pipettes}

For the series of gray pipettes the adhesive tape was first applied to the outside of the pipettes in the same manner as for the colored ones. White 0 was constructed by first whitening the surface of the tape with shoe whitening and, after drying, the whole was rubbed with hard paraffin. Grays 1-6 inclusive 
were obtained by dipping the tapecovered pipettes into black India ink of different dilutions. Paraffin was applied to the dried outer surface of the pipettes. Black 7 was the result of rubbing a covered pipette with a black wax crayon and then paraffining it.

Measurements of the relative light reflection of these gray pipettes were made with a MacBeth illuminometer. A petri dish filled with water was placed upon a milk glass plate and 2 inches above the surface of the water the illuminometer was directed in such a manner that light, emitted from a light source making an angle of 60 degrees with the water surface, was reflected up into the illuminometer at the same angle, fig. 3 . The pipettes were lowered one by one just beneath the surface of the water of the petri dish and the relative values of the light reflected from the side of each was measured.

The relative brightnesses of the pipettes as measured by this method were as follows:

White $0 \ldots \ldots 63$
Gray $1 \ldots \ldots .49$
Gray $2 \ldots \ldots$
Gray $3 \ldots \ldots .26$
Gray $4 \ldots \ldots .21$
Gray $5 \ldots \ldots$
Gray $6 \ldots \ldots$
Black $7 \ldots \ldots$.

It is thus seen that the range of intensity of the gray pipettes was considerable and it was very reasonable to expect that it would cover the range of intensities of the colors used.

\section{Color Rods}

From a good quality, $1 \mathrm{~mm}$. thick, water-color board, small 6 by $65 \mathrm{~mm}$. strips were cut. Twenty-eight of these were painted with water colors in such a way that the strips could be arranged in to a complete visible spectrum divided into 28 grades of color of roughly equal degrees of difference. The stages were made by imitating the pure spectral colors given by Ridgway in his "Color Standards and Color Nomenclature." The colored paper rods were finally dipped in warm paraffin to render them waterproof and to obviate any possible odor of the pigments. The paraffin coating had practically no detrimental effect as far as changing the original color was concerned.

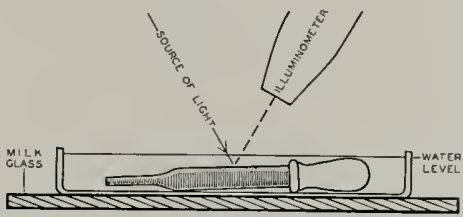

Fig. 3.-Method used to determine the relative brightness of the gray pipettes.

The following is a list of the 28 colors in order from red to violet:

1. Spectrum red

2. Scarlet red

3. Scarlet

4. Grenadine red

5. Flame scarlet

6. Orange chrome

7. Cadmium orange

8. Orange

9. Cadmium yellow

10. Light cadmium

11. Lemon chrome

12. Lemon vellow

13. Greenish yellow

14. Bright greenyellow
15. Neva green
16. Emerald green
17. Vivid green
18. Skobeloff green
19. Benzol green
20. Italian blue
21. Cerulean blue
22. Methyl blue
23. Spectrum blue
24. Bradley's blue
25. Pheny] blue
26. Blue-violet
27. Bluish violet
28. Spectrum violet

\section{TRAINING AND RESPONSES OF LARGE-MOUTH BLACK BASS \\ Method}

In all the training experiments the fish were shown a number of pipettes one after another. From a particular pipette the fish were fed either Daphnia or mosquito larvae, whereas from all the others nothing was fed, but instead, if the fish approached closer than a certain distance from the pipette a shock was given. In some of the training experiments that distance was $6 \mathrm{~cm}$. and in others it was $3 \mathrm{~cm}$. Whenever the same series of pipettes was shown to a fish time after time, the sequence was continually changed in order that the responses of the fish could not possibly be a result of a learned sequence, but rather must be a response unmodified by anything other than color or intensity. That the presence of the living food in the pipette might have had some attracting influence upon the fish was highly improbable. It was impossible that the effect could be chemical for the fish responded within a second or two 
and from a distance ranging from two to $15 \mathrm{~cm}$. from the entering pipette. The other possibility, that the bass might have heard the swimming movements of the Daphnia or mosquito larvae, was eliminated by repeatedly presenting an empty pipette of the color to which the fish was trained and obtaining exactly the same results as when food was present. Furthermore, of the pipette and then retreat. The distance they would retreat was inversely related to the frequency with which they struck. A well trained fish would strike repeatedly at its own color, retreating very little between strikes. Occasionally it would strike at another color but in this case it would rapidly retreat considerably farther and appear very timid. Striking a color other than

Table 1. - The distance away in $\mathrm{cm}$. that each of 12 untrained black bass remained from colored, black and light gray pipettes. Each value is the average of four traials.

\begin{tabular}{|c|c|c|c|c|c|c|}
\hline $\begin{array}{l}\text { FISH } \\
\text { No. }\end{array}$ & $\begin{array}{c}\text { Rose } \\
\text { RED }\end{array}$ & $\begin{array}{l}\text { LEMON } \\
\text { YELLOW }\end{array}$ & $\begin{array}{c}\text { SCHEELE'S } \\
\text { GREEN }\end{array}$ & $\begin{array}{c}\text { Helvetia } \\
\text { Blue }\end{array}$ & GRAY 1 & BLACK 7 \\
\hline $\begin{array}{l}19 \\
20 \\
21 \\
22 \\
23 \\
24 \\
25 \\
26 \\
27 \\
28 \\
29 \\
30 \\
\text { Average* }\end{array}$ & $\begin{array}{l}1.5 \\
1.5 \\
2 . \\
1.5 \\
1.5 \\
1.5 \\
1 . \\
1.5 \\
1 . \\
11.75 \\
5.25 \\
1.5 \\
1.75\end{array}$ & $\begin{array}{l}1 . \\
1.5 \\
1 . \\
1.5 \\
1.5 \\
2 . \\
2 . \\
1 . \\
2 . \\
11.75 \\
4 . \\
3.25 \\
1.88\end{array}$ & $\begin{array}{l}3 . \\
2.5 \\
2 . \\
1 . \\
2 . \\
2.5 \\
2.5 \\
1 . \\
1.5 \\
13 . \\
7.25 \\
2 . \\
2.48\end{array}$ & $\begin{array}{l}2 . \\
2 . \\
1.5 \\
1 . \\
3 . \\
3.5 \\
3.25 \\
2 . \\
1.5 \\
13 . \\
7.25 \\
2.5 \\
2.68\end{array}$ & $\begin{array}{l}1 . \\
2 . \\
1 . \\
1 . \\
1.5 \\
1.5 \\
2 . \\
1 . \\
2 . \\
13 . \\
6.5 \\
2.5 \\
2 .\end{array}$ & $\begin{array}{l}1.5 \\
2.25 \\
1 . \\
1.5 \\
3.5 \\
3.5 \\
2 . \\
1.5 \\
3 . \\
13 . \\
7.25 \\
3 . \\
2.68\end{array}$ \\
\hline
\end{tabular}

"This average does not include fish No. 28, which showed no active response.

the same response of the fish could be obtained by holding the pipette just above the surface of the water. Without the continuity of water between the food and the fish sound could not have travelled from one to the other with intensity sufficient to have evoked response from the fish. A further check was made by putting the food material into all the pipettes used. The responses remained unaffected.

Three seconds was the time given the fish to respond to the pipette. At the end of this time the position of the fish was recorded and food was ejected from the end of the pipette to which the fish was being trained, or, the animal was shocked if it was within the "limit" distance from any pipette other than its training color. All the records are statements of the distance from the end of the pipette at which the fish was found the moment the observation was completed. The fact that no observations of less than about half a centimeter were recorded was a result of the manner in which the bass responded to a pipette. They would strike at the end its own seemed to be very frequently a result of the habit of bass of striking at moving objects. These strikes would usually occur about the time the pipette touched the surface of the water. These facts suggested that the distance from the end of the pipette at which a fish was found three seconds from the time the pipette broke the surface of the water was a sufficiently faithful representation of the strength of the positive or negative reaction of trained fish.

Another variable with which it was necessary to cope was the hunger of the fish. A fish which was hungry would remain nearer the pipette, on the average, than one which was not hungry. It seemed safer therefore, for the sake of obtaining more or less comparable results, to keep the fish hungry throughout the experimentation. A few initial experiments were carried out to determine the capacity of bass for Daphnia. It was determined that a well fed bass of the size which were used would eat at the rate of one Daphnia every five to eight minutes, and that a bass that had not been fed for about six hours would 
Table 2.- Records obtained during the training of bass to approach one cf the four colors, rose red, lemon yellow, Scheele's green, or Helvetia blue, and at the same time retreat from the other three colors. Each value for an individual fish is the average number of $\mathrm{cm}$. a fish remained away from the color during five training trials.

eat rapidly and continuously from 15 to 20 of these. In all the experiments at training and measuring response this capacity was borne in mind and a safe margin of hunger was always maintained. With practically no exceptions the bass eyed attentively all the pipettes and rods which were shown them and their other general movements and behavior also indicated clearly to an observer that the fish were actively responding to them.

\section{Reactions of Untrained Fish to Colors and Grays}

Bass Nos. 19 to 30 inclusive were placed in the individual, white enameled training dishes and Daphnia were added to the water. At first the fish refused to eat and were very nervous. They were permitted to remain unmolested until they had become accustomed to their new surroundings, which required two or three days. At the end of this time they would dash to a pipette and strike futilely at a Daphnia which was clearly visible through the glass wall and then promptly seize the Daphnia when it was ejected from the end.

These fish were now considered sufficiently at ease in their laboratory environment to permit a fair test of the responses of the untrained fish to rose red, lemon yellow, Scheele's green, Helvetia blue, gray 1 and black 7 . The same procedure as in training was used except that here there was neither food nor shock associated with the pipettes. The series was shown to each fish four times over a period of two days. The average distance away from each pipette for each fish for the four trials was recorded to the nearest half of a centimeter and can be seen in Table 1 .

These results indicated that red was the most attractive color; yellow was next; then in order came light gray, green, blue and black. This experiment presented reactions upon which the modification of response in the bass

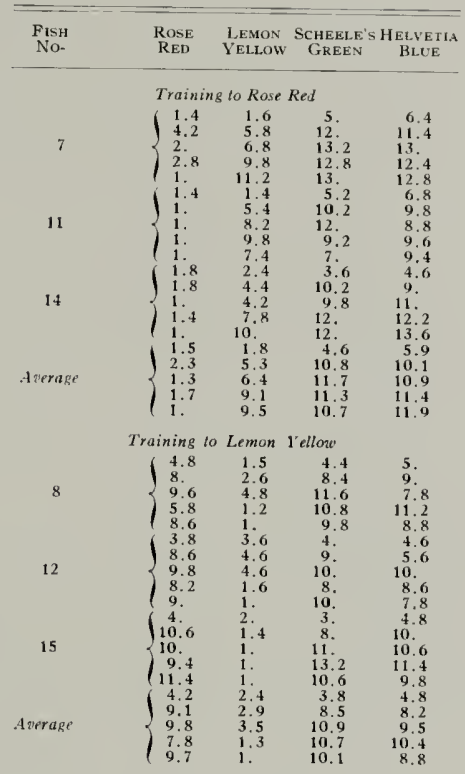

Training to Scheele's Green

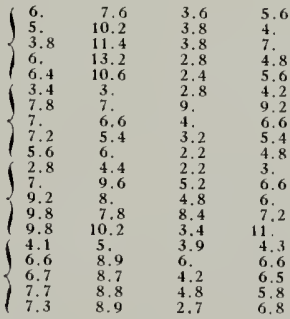

Training to Helvetia Blue

$\left\{\begin{array}{rrrr}8.4 & 7.6 & 8.2 & 8 . \\ 9.6 & 7.4 & 8.2 & 7.2 \\ 8.2 & 8.2 & 5.6 & 6.4 \\ 6.2 & 8.4 & 5.8 & 5.8 \\ 7.4 & 6.8 & 6.4 & 4.4 \\ 4.4 & 3.6 & 5.2 & 5.4 \\ 7.4 & 8.2 & 8.6 & 6.2 \\ 5.6 & 5.4 & 5 . & 6.6 \\ 8.4 & 10 . & 8.2 & 5.4 \\ 11.6 & 7.4 & 10.4 & 8.6 \\ 4.8 & 4.8 & 6.8 & 6.8 \\ 4.8 & 6.8 & 4.6 & 5.4 \\ 4.6 & 7.6 & 4.2 & 3.2 \\ 8.2 & 6.6 & 6.6 & 3.2 \\ 6.2 & 7.6 & 7.4 & 2.6 \\ 5.9 & 5.3 & 6.7 & 6.7 \\ 7.3 & 7.5 & 7.1 & 6.3 \\ 6.1 & 7.1 & 4.9 & 5.4 \\ 7.6 & 8.3 & 6.9 & 4.7 \\ 8.4 & 7.3 & 8.1 & 5.2\end{array}\right.$




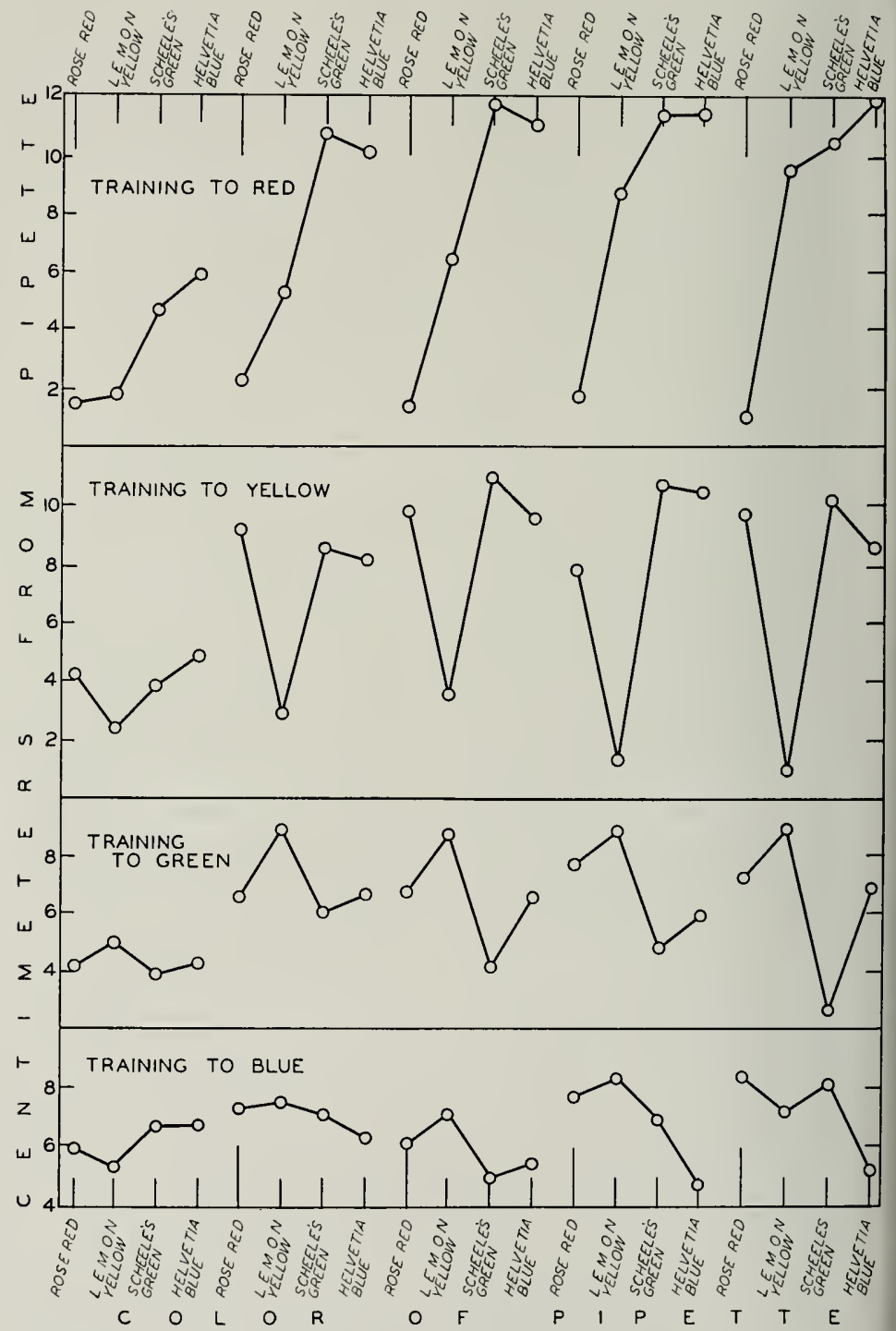

Fig. 4.-Average data for groups of three fish trained to each color, showing stages in the learning process. See Table 2 . 
was to be superimposed. It was borne in mind, however, that the attractiveness of red for the fish might have been the result of the feeding upon Daphnia which were reddish brown.

\section{Training to Each of Four Colors}

Twelve bass were now subjected to training to four colors. Numbers 7, 11 and 14 were trained to rose red as contrasted with Scheele's green, lemon yellow and Helvetia blue; Nos. 8, 12 and 15 were trained to lemon yellow as contrasted with the other three colors; Nos. 9, 13 and 16 were trained to Scheele's green, and Nos. 6, 10 and 17 to Helvetia blue as contrasted with the remaining three colors. Throughout this experiment the bass were fed Daphnia from the pipette of their training color and were shocked whenever they were less than $6 \mathrm{~cm}$. from the end of any other pipette after three seconds had elapsed. Each fish was shown the series of four pipettes five times each half day for two and a half days. At the end of this period the fish were considered trained for the purposes of the experiment.

Table 2 and fig. 4 show the records that were obtained during the course of the training of these fish. The average of each group of five trials on each color has been calculated and every record in the table is thus an average of five

Table 3.- The average distance in $\mathrm{cm}$. away from colors and grays that color-trained fish remained. Each value is the average of nine trials taken with three fish.

\begin{tabular}{|c|c|c|c|c|}
\hline & $\begin{array}{c}\text { TRAINED } \\
\text { TD } \\
\text { RED }\end{array}$ & $\begin{array}{l}\text { Trained } \\
\text { TO } \\
\text { YELLOW }\end{array}$ & $\begin{array}{l}\text { TRAINED } \\
\text { TO } \\
\text { GREEN }\end{array}$ & $\begin{array}{c}\text { TRAINED } \\
\text { TD } \\
\text { BLUE }\end{array}$ \\
\hline Rose Red & 1. 22 & 4.38 & 5. & +.5 \\
\hline Scarlet. & 1. 56 & 3.38 & 5.33 & 4.17 \\
\hline Shrimp pink & 1.75 & 2.33 & 5.17 & 5.5 \\
\hline Flame scarlet & i. 22 & 5.13 & 5.5 & 5.34 \\
\hline Lemon yellow & 5.8 & 1.88 & 4.66 & 6. \\
\hline Scheele's green & 7.23 & 5.63 & 1.84 & 1.5 \\
\hline Meadow green & 7. & 6.13 & 1.5 & 1.5 \\
\hline Helvetia blue & 7.23 & 6.88 & 1.33 & 1.33 \\
\hline Seal brown & 6.78 & 7.38 & 1.33 & 1.5 \\
\hline Gray 1 & 5.9 & 1.12 & 5.33 & 5.33 \\
\hline Gray 2 & 5.77 & 1.62 & 4.17 & 4.67 \\
\hline Gray 3 & 5.9 & 3.62 & 3.66 & 3.66 \\
\hline Gray 5 & 6.66 & 6.5 & 2.67 & 2.17 \\
\hline Gray 6 & & 6.13 & 2.5 & 1.33 \\
\hline Gray 7 & 7.23 & 6.63 & 2 . & 1.5 \\
\hline
\end{tabular}

trials. From this data a series of curves illustrating the learning process has been constructed. These indicate that even at the end of six to eight trials the bass have become considerably modified in their behavior towards the colors. The learning with respect to the red and yellow has been most striking and that to green and blue much less so. Thus, for the same kind of training for the same length of time the results of training to the four colors are by no

Table 4.- Results obtained in an attempt to train yellow-trained fish to approach lemon yellow and retreat from gray 1 and 2 and shrimp pink. Values for individual fish are average distances in $\mathrm{cm}$. from the pipettes for 10 training trials.

\begin{tabular}{|c|c|c|c|c|}
\hline $\begin{array}{l}\text { FISH } \\
\text { No. }\end{array}$ & $\begin{array}{l}\text { LEMON } \\
\text { YELLOW }\end{array}$ & GRAY 1 & GRAY 2 & $\begin{array}{c}\text { SHRIMP } \\
\text { PIXK }\end{array}$ \\
\hline $\begin{array}{c}8 \\
12 \\
15 \\
\text { Average }\end{array}$ & $\begin{array}{l}8.09 \\
3.63 \\
+.81 \\
5.51\end{array}$ & $\begin{array}{l}7.54 \\
5 . \\
6.45 \\
6.3 .3\end{array}$ & $\begin{array}{l}7.81 \\
3.63 \\
5.63 \\
5.60\end{array}$ & $\begin{array}{l}9.27 \\
4.41 \\
6.72 \\
6.8\end{array}$ \\
\hline
\end{tabular}

means identical. The probable significance of these results will become more evident later.

\section{Responses of Fish Trained to Four Colors}

Having completed their training, bass Nos. 6-17 inclusive were next shown a series of pipettes including the colors with which they had been trained. In addition there were several strange colors and shades of gray. During this experiment the fish were neither fed nor shocked, the distance away from the end of the pipette after an interval of three seconds being taken as an index of the degree of attraction of the color for the particular bass. Each bass was shown each color in the series three times, and consequently with three bass trained to each one of the four colors nine observations were available for averaging to determine the response of bass trained to a particular color, to other colors and grays. The following were the colors used in this experiment: Rose red, scarlet, shrimp pink, flame scarlet, lemon yellow, Scheele's green, meadow green, Helvetia blue, seal brown, gray 1 , gray 2 , gray 3 , gray 5 , gray 6 and black 7 . Table 3 and fig. 5 give the average distance that fish trained to each of the four colors remained away from each pipette. The results for individual fish were remarkably similar.

It is of great interest to note that redtrained fish selected all colors having a 


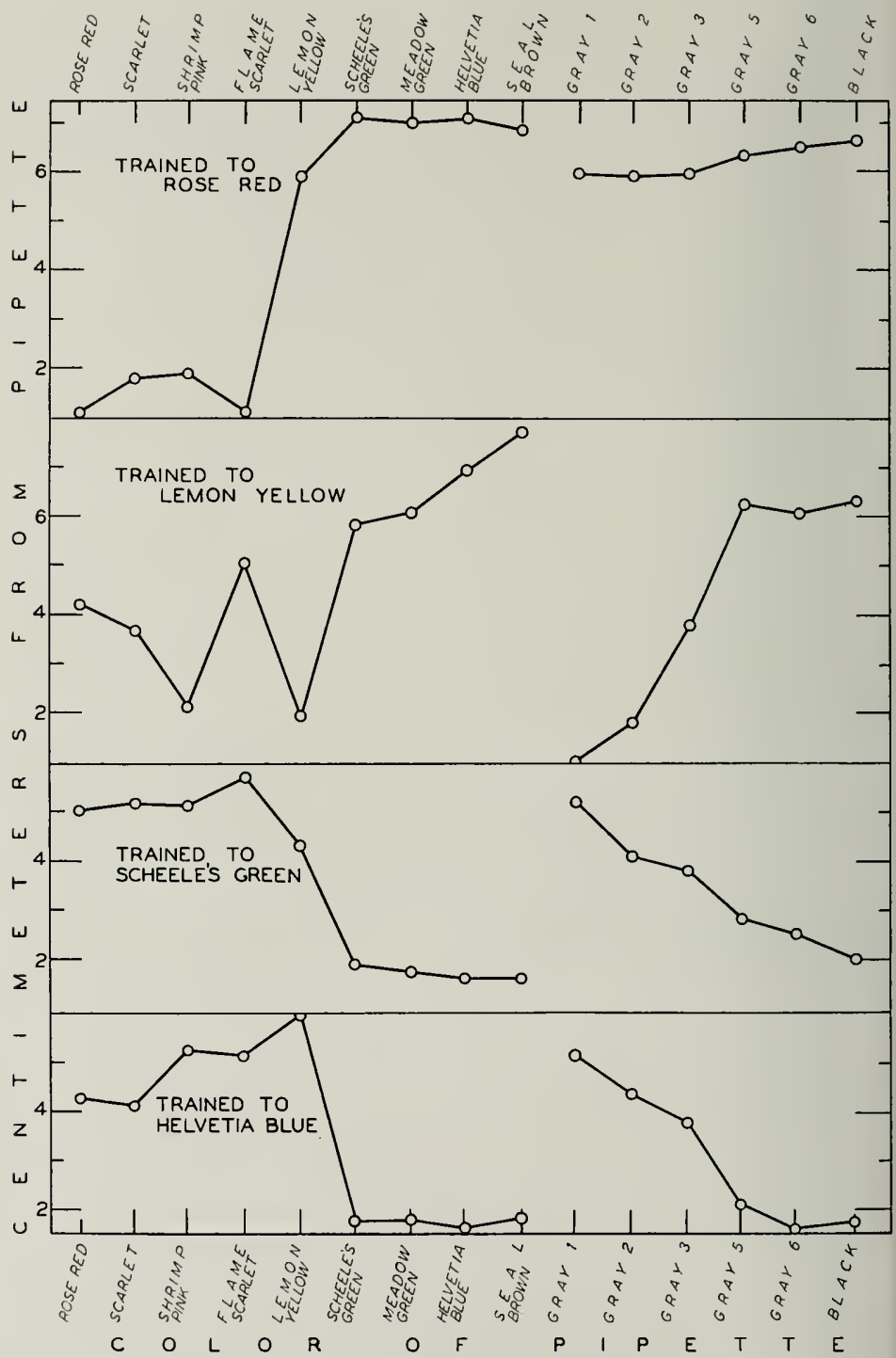

Fig. 5.-Responses of trained bass Nos. 6-17 to variously colored pipettes. The pipettes are the same as in Table 3 . 
reddish tint in strong contrast to all other colors and shades of gray, and secondly, that among the grays the light grays were slightly more attractive to these fish than were the dark.

Fish trained to yellow were not nearly so color specific but responded equally well to the lightest gray and to the yellow to which they were trained. They were also somewhat positive to shrimp pink, a very pale-colored pipette.

Lastly, fish trained to green or blue were almost equally positive to green, blue and dark grays. Inlike the fish trained to red and yellow, these fish were quite negative to the light grays.

In the light of the similarity of yellow, light grays and shrimp pink to animals trained to yellow it was deemed advisable to determine whether the fish had been trained to yellow only as a bright pipette because no other equally bright color was present in the original training series, or whether it was because the fish distinguished very little between yellow and light gray. Five trials training to lemon yellow in contrast to gray 1 , gray 2 and shrimp pink pipettes were given to each of the fish trained to yellow and then the average of the next 10 trials (still training trials, i.e., feeding upon yellow and shocking upon the other pipettes) was taken as a criterion of the degree of learning of the fish. The original training had shown that five to eight trials were sufficient to produce a strikingly modified behavior to pipettes the colors or intensities of which were quite distinct for the fish. Table 4 gives the averages of the 10 trials for each of the fish.

Still a light gray and the yellow were quite indistinguishable and the very pale reddish pipette, shrimp pink, was becoming the most different from the yellow though to the human eye it appeared of a brightness intermediate between the two lightest shades of gray. In other words, here again red was distinctive.

Bass were next shown two pipettes simultaneously in order to determine what the effects of choice would be. The pipettes were placed $7 \mathrm{~cm}$. apart in a metal rack and then the rack lower- ed in such a fashion that the pipettes broke the surface of the water at the same instant. When the fish struck at one of the pipettes or remained before one for two seconds, that pipette was

Table 5.- Choice of fish trained to each of four cclors when presented simultaneously with two colors.

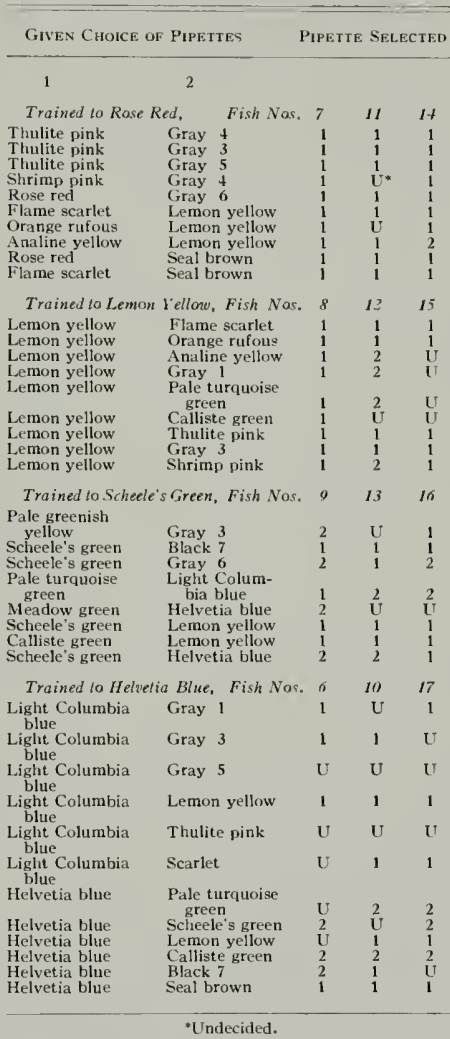

regarded as the choice of the fish. On the other hand, if the fish approached neither or swam back and forth between them, then the response of the fish was termed "undecided." Table $\mathbf{5}$ gives the results of these experiments.

Glancing through this table we are again impressed with the distinctness 
of red as a color. Several different reds were selected very decisively from a number of confusing colors and grays. The blues, greens and grays appeared to be more or less confused by the fish, the blues being the most often confused with grays. from those other colors shown it. The results of 30 training trials made after the completion of the first 10 trials were averaged together and are shown in Table 6 and fig. 6 . The results are fully comparable since all the fish had had equivalent training.

Table 6.-Results of a second experiment of training fish to approach certain colors and to retreat from others. Each value for individual fish is the average distance from the pipettes in $\mathrm{cm}$. for 30 training trials after the initial 10 training trials have been excluded.

\begin{tabular}{|c|c|c|c|c|c|c|}
\hline $\begin{array}{l}\mathrm{F}_{1 \mathrm{sH}} \\
\text { No. }\end{array}$ & $\begin{array}{c}\text { Rose } \\
\text { RED }\end{array}$ & $\begin{array}{l}\text { Flame } \\
\text { Scarlet }\end{array}$ & $\begin{array}{l}\text { LEMON } \\
\text { YELLOW }\end{array}$ & GRAY 1 & $\begin{array}{c}\text { ScheEle's } \\
\text { GREEN }\end{array}$ & $\begin{array}{c}\text { Helvetia } \\
\text { Blue }\end{array}$ \\
\hline \multicolumn{7}{|c|}{ Trained to Rose Red } \\
\hline 19 & 3.45 & 3.9 & 5.41 & & 4.4 & 4.5 \\
\hline 23 & 2.3 & 2.89 & 4.35 & & 5.15 & 5.23 \\
\hline Average & 2.88 & 3.39 & 4.88 & & 1.82 & 1.81 \\
\hline 27 & 4.3 & & 5.96 & & 6.25 & 7.16 \\
\hline \multicolumn{7}{|c|}{ Trained to Lemon Yellow } \\
\hline 20 & 5.55 & & 4.05 & 4.93 & 6.0 .5 & 7. \\
\hline 24 & 3.26 & & 1. 89 & 2.37 & 3.52 & 4.2 \\
\hline Average & 4.4 & & 2.97 & 3.65 & 4.78 & 5.6 \\
\hline 28 & 8.12 & & 5.91 & & 11.3 & 10.98 \\
\hline \multicolumn{7}{|c|}{ Trained to Scheele's Green } \\
\hline 21 & 6.65 & & 5.98 & & 4.74 & 5.61 \\
\hline 25 & 4. & & 3.68 & & 2.23 & 3. \\
\hline Average & 5.33 & & 4.83 & & 3.48 & 4.3 \\
\hline 29 & 5.24 & & 4.43 & & 2.39 & \\
\hline \multicolumn{7}{|c|}{ Trained to Helvetia Blue } \\
\hline 22 & 5.4 & & 5.88 & & 2.9 & 2.4 \\
\hline 26 & 5.65 & & 4.77 & & 3.78 & 2.67 \\
\hline Average & 5.53 & & 5.33 & & 3.34 & 2.54 \\
\hline 30 & 3.57 & & 2.98 & & & 2.26 \\
\hline
\end{tabular}

\section{Training to Each of Four Colors Plus Tints}

The usual training procedure was now applied to bass Nos. 19-30 inclusive, except that in this instance shocking was employed only when the fish came within a distance of $3 \mathrm{~cm}$. from a pipette other than the one to which they were being trained. After 10 training trials the fish were considered sufficiently trained. Unlike the first training experiment, two of the three fish trained to rose red were trained against flame scarlet in addition to lemon yellow, Scheele's green and Helvetia blue; and two of those fish trained to lemon yellow had gray 1 included among those colors to which they were shocked upon too close approach. Also, one of the fish trained to green had blue omitted, and one of the fish trained to blue had green omitted
Here, the similarities between red and flame scarlet and between yellow and light gray are shown in relatively measurable quantities. There is seen repeated the difficulty of the fish in distinguishing between green and blue. Again there is indicated a greater distinctness of red than any other color. In short, the results of this second training experiment with a new lot of animals have corroborated the results obtained in the first one in many fundamental respects.

With the disadvantage of not knowing at what brightnesses the training colors appeared to the bass it was impossible to make a complete comparison of the apparent colorfulnesses of the pipettes used, for it was unknown whether the response difference between some colors was partly due to brightness, or even wholly so. Presenting the 
shades of gray to the first lot of bass had given a clue that seemed worth following up. Did rose red and lemon yellow actually appear to the fish as bright colors and did Helvetia blue and Scheele's green appear as colors of low intensity? To the light-adapted human at ahout this time, the number of trials that are available for red is somewhat smaller. One red-trained animal was given 15 series, and the only one which survived at the end of the training, No. 27 , was given 35 series.

The results of this experiment are

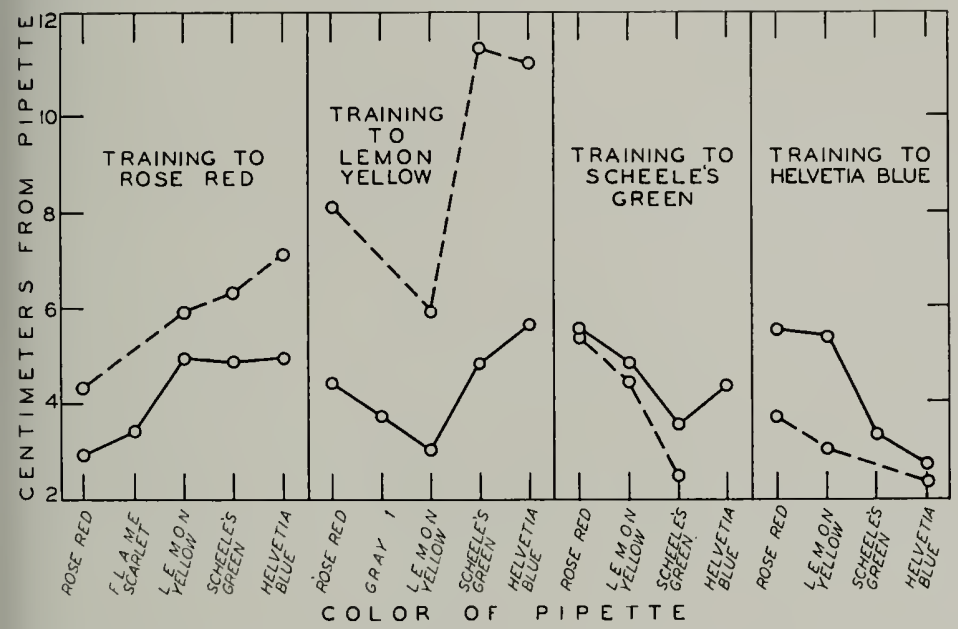

Fig. 6.- Responses of trained bass Nos. 19-30. See Table 6. The broken line is the result obtained with those fish trained with the shorter series of colors in each case.

eye Scheele's green and rose red appeared of approximately equal intensity, about that of gray 3 or 4 , the red being perhaps a trifle darker. The yellow appeared about as gray 1 and the blue as gray 6 . It was deemed profitable to repeat the work upon the response of trained fish to shades of gray.

\section{Responses of Fish Trained to Four Colors Plus Tints}

Response to Color and Three Shades of Gray.- Each of the 12 bass was now subjected to a secondary training in which the color to which the bass had previously been trained and the three shades of gray-gray 1, gray 4 and black 7 , were used. Thirty training series were given to each of the fish trained to yellow, green and blue. Due to the misfortune of having two of the fish trained to red leap out of their pans given in Table 7 and fig. 7 . These re sults parallel those of the earlier work. Animals trained to red and yellow are most attracted by the light grays and those trained to green and blue are most attracted by the dark grays. This differential response continued without abatement over the 30 trials and hence it appears a very plausible conclusion that the bass see lemon yellow and rose red as colors of high intensity, and Scheele's green and Helvetia blue as colors of low intensity.

Again the red pipette was the most distinctive one for the bass, judging from the difference in response between the red and the nearest shade of gray. Upon this same basis, green came next, yellow next, and finally blue, the response to which was for all practical purposes just like that to black. The next question to be answered was 
Table 7.-Data obtained in teaching trained fish to approach the color toward which they had been trained and to retreat from each of three shades of gray. Each value for individual fish is the average distance in $\mathrm{cm}$. the fish remained away from the color during five training trials.

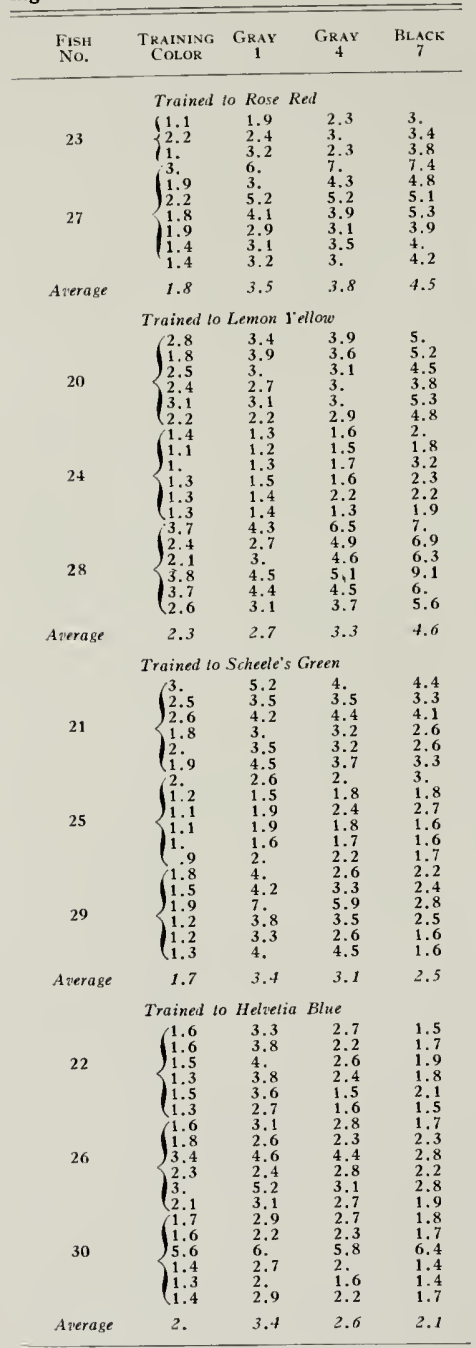

whether these apparent distinctivenesses of the colors were related in any way to differences in intensity, for the bass, of the particular colors used and the nearest gray. For example, was yellow more nearly like gray 1 in intensity than was red, and similarly was blue much more nearly like black for the fish than was green?

The obvious solution to the problem lay in the use of a longer series of grays and determining what shade of gray most closely resembled the intensity of the color for the fish. This would establish conclusively whether red and green were actually the colors most easily distinguished from any shade of gray for the bass.

Response to Color and Eight Shades of Gray.-The bass were individually trained with a series of grays, white 0 , gray 1 , gray 2 , gray 3 , gray 4 , gray 5 , gray 6 and black 7 , and the certain color to which each fish had been trained. The usual procedure was followed, the fish being fed in this instance mosquito larvae upon its own color and shocked whenever it came within $3 \mathrm{~cm}$. of any one of the grays. With the exception of the fish trained to red, each fish was given 20 training series. This red-trained fish was given $\mathbf{5 0}$ series since it was desirable to have a good number of observations for averaging. The results of this experiment are recorded in Table 8 and fig. $8, \mathrm{~A}$.

Now, the conclusions reached in the training of fish to three shades of gray have become more evident. Blue is seen to be closest to black 7 in intensity for the fish, green most closely resembles gray 6 , yellow resembles gray 1 or 2 , and red appears about the same intensity as the yellow and light grays, but due to the apparent distinctiveness of red as a color set apart from every other color and shade of gray it is considerably more difficult to determine which shade of gray is most like red.

The differences in the responses of the fish to their training color and to the shade of gray which most closely resembles it have become more obvious and it is seen still that red is the most distinct color a bass sees and green is second in that respect. Yellow is some- 
Table 8.-Data obtained in teaching trained fish to approach the color toward which they had been trained and to retreat from each of eight shades of gray. Each value for individual fish is the average distance in $\mathrm{cm}$. the fish remained away from the color during five training trials.

\begin{tabular}{|c|c|c|c|c|c|c|c|c|c|}
\hline $\begin{array}{l}\text { Fish } \\
\text { No. }\end{array}$ & $\begin{array}{c}\text { Training } \\
\text { Color }\end{array}$ & $\begin{array}{c}\text { White } \\
0\end{array}$ & $\begin{array}{c}\text { GRAY } \\
1\end{array}$ & $\begin{array}{c}\mathrm{GRAY}^{*} \\
2\end{array}$ & $\begin{array}{c}\text { GRAY } \\
3\end{array}$ & $\begin{array}{c}\text { GraY } \\
4\end{array}$ & $\begin{array}{c}\text { GRAY } \\
5\end{array}$ & $\begin{array}{c}\text { Gray } \\
6\end{array}$ & $\begin{array}{c}\text { BLACK } \\
7\end{array}$ \\
\hline \multicolumn{10}{|c|}{ Trained to Rose Red } \\
\hline 27 & $\left\{\begin{array}{r}1.2 \\
1.4 \\
.9 \\
1.1 \\
.9 \\
.9 \\
.7 \\
.9 \\
.8 \\
.9\end{array}\right.$ & $\begin{array}{l}2.8 \\
3.4 \\
3.4 \\
3.7 \\
3.2 \\
3 . \\
2.9 \\
2.6 \\
3.3 \\
3.1\end{array}$ & $\begin{array}{l}2.8 \\
3.3 \\
3.3 \\
3.6 \\
2.3 \\
3.1 \\
2.3 \\
2.8 \\
3.2 \\
2.9\end{array}$ & $\begin{array}{l}2.2 \\
3 . \\
4.6 \\
4.8 \\
2.5 \\
2.2 \\
2.4 \\
3.4 \\
3 . \\
3.3\end{array}$ & $\begin{array}{l}2.8 \\
4.3 \\
4.2 \\
4.4 \\
2 . \\
3.9 \\
2.9 \\
3.1 \\
2.4 \\
3.7\end{array}$ & $\begin{array}{l}2.6 \\
4.3 \\
4.6 \\
3.9 \\
2.4 \\
3.7 \\
2.2 \\
4.1 \\
2.7 \\
2.6\end{array}$ & $\begin{array}{l}3.7 \\
3.5 \\
5.2 \\
4.3 \\
3.5 \\
2.4 \\
3 . \\
3.3 \\
3.3 \\
3.7\end{array}$ & $\begin{array}{l}3.3 \\
4.3 \\
4.3 \\
5 . \\
2.7 \\
3.5 \\
2.8 \\
4.4 \\
3.6 \\
2.5\end{array}$ & $\begin{array}{l}3.7 \\
4.2 \\
3.7 \\
3.9 \\
3 . \\
3.6 \\
2.4 \\
4 . \\
3.7 \\
3.6\end{array}$ \\
\hline toerage & 1. & 3.2 & 3. & 3.2 & 3.7 & $3 .+$ & 3.7 & 3.6 & 3.6 \\
\hline
\end{tabular}

\section{Trained to Lemon Fellow}

\begin{tabular}{|c|c|c|c|c|c|c|c|c|c|}
\hline \multirow{4}{*}{20} & 2.8 & 3.4 & 2.4 & 3.5 & 2.5 & 7.1 & 5.5 & 6.5 & 8. \\
\hline & 22.7 & 3.9 & 3.5 & 2.8 & 3.3 & 3.4 & 5.9 & 5.3 & 6.4 \\
\hline & 3.3 & 6.2 & 6.1 & 7.4 & 9.6 & 8.1 & 7.2 & 12. & 10.6 \\
\hline & 13.1 & 4.4 & 3.7 & 4. & 6.4 & 6.3 & 8.6 & 8.3 & 9. \\
\hline \multirow{5}{*}{24} & (1.4) & 1.8 & 1.5 & 1.7 & 1.9 & 2.1 & 2.3 & 2.9 & 2.5 \\
\hline & $\int 1.3$ & 1.6 & 1.5 & 2. & 2. 2 & 2.3 & 2. & 2.3 & 3. \\
\hline & $\{1.4$ & 1.4 & 1.3 & 1.6 & 1.7 & 1.7 & 2. & 1.9 & 2.8 \\
\hline & 11.2 & 1.4 & 1.3 & 1. 4 & 1.9 & 2.2 & 1.9 & 2 & 2.3 \\
\hline & 3.6 & 7. & 5.9 & 4.9 & 7.2 & 6.5 & 8.7 & 7.4 & 9.1 \\
\hline \multirow{3}{*}{28} & 2.6 & 7. & 6. & 5. & 7.1 & 5.6 & 7. & 7.4 & 8.6 \\
\hline & 2,5 & 4.6 & 4.2 & 4. 1 & 4.8 & 5.7 & 6.6 & 9.2 & 7.6 \\
\hline & 12.6 & 3.9 & & 2.9 & 3.9 & 4.3 & 6.1 & 6.5 & 6. \\
\hline rage & 2.3 & 30 & 34 & $3 . t$ & $4 . t$ & 4.6 & 5.3 & 6. & 6.5 \\
\hline
\end{tabular}

Trained to Scheele's Green

$\begin{array}{lllllll}4.9 & 4.3 & 4.3 & 4.8 & 4.5 & 3.2 & 4.4 \\ 5.1 & 4.6 & 4.8 & 5.6 & 4.6 & 2.7 & 2.9 \\ 6.5 & 6.5 & 7.3 & 3 . & 6.3 & 5.1 & 5.8 \\ 5.5 & 4.3 & 5.7 & 6.1 & 3.7 & 1.9 & 3.1 \\ 2.5 & 2.1 & 2.3 & 1.9 & 1.9 & 2.3 & 2.1 \\ 2.6 & 2.5 & 2.8 & 2.2 & 2.9 & 2.4 & 2.2 \\ 2.7 & 2.7 & 2.6 & 2.3 & 2.2 & 2.4 & 2.2 \\ 3.3 & 4.4 & 2.8 & 3.9 & 2.4 & 1.9 & 2.4 \\ 3.5 & 4.5 & 3.8 & 2.9 & 2.9 & 1.9 & 2.5 \\ 3.2 & 2.7 & 3.5 & 2.7 & 2.8 & 1.7 & 2.5 \\ 4 . & 3 . & 2.5 & 2.4 & 2.9 & 2.9 & 3.1 \\ 2.6 & 2.8 & 2.4 & 2.4 & 1.6 & 2.1 & 2 . \\ 3.9 & 3.7 & 3.7 & 3.4 & 3.2 & 2.5 & 2.9\end{array}$

Trained to Ilelvetia Blue

$\begin{array}{lllllll}4.3 & 3.3 & 3.1 & 3.3 & 2.3 & 1.4 & 1.7 \\ 2.4 & 2.2 & 2 . & 1.7 & 1.7 & 1.5 & 1.6 \\ 3.2 & 1.5 & 1.6 & 1.8 & 1.7 & 1.2 & 1.1 \\ 2.8 & 1.8 & 1.8 & 1.6 & 1.4 & 1.5 & 1.3 \\ 3.7 & 2.7 & 2.9 & 2.5 & 2 . & 1.7 & 1.5 \\ 2.7 & 3.2 & 2.8 & 3.3 & 2.9 & 2.5 & 2.4 \\ 4.2 & 3.6 & 3.9 & 3.3 & 2.5 & 2.1 & 1.7 \\ 3.8 & 3.7 & 2.3 & 2.6 & 2.3 & 2.9 & 1.6 \\ 2.8 & 3.1 & 3.7 & 1.7 & 2.2 & 2.9 & 2.7 \\ 2.2 & 2.1 & 1.9 & 1.9 & 1.9 & 1.7 & 1.5 \\ 2.4 & 2.7 & 3.5 & 2.6 & 2.1 & 1.6 & 1.6 \\ 2 . & 1.7 & 1.6 & 1.6 & 1.5 & 1.2 & 1.3 \\ 3 . & 2.6 & 2.6 & 2.4 & 2 . & 1.8 & 1.6\end{array}$




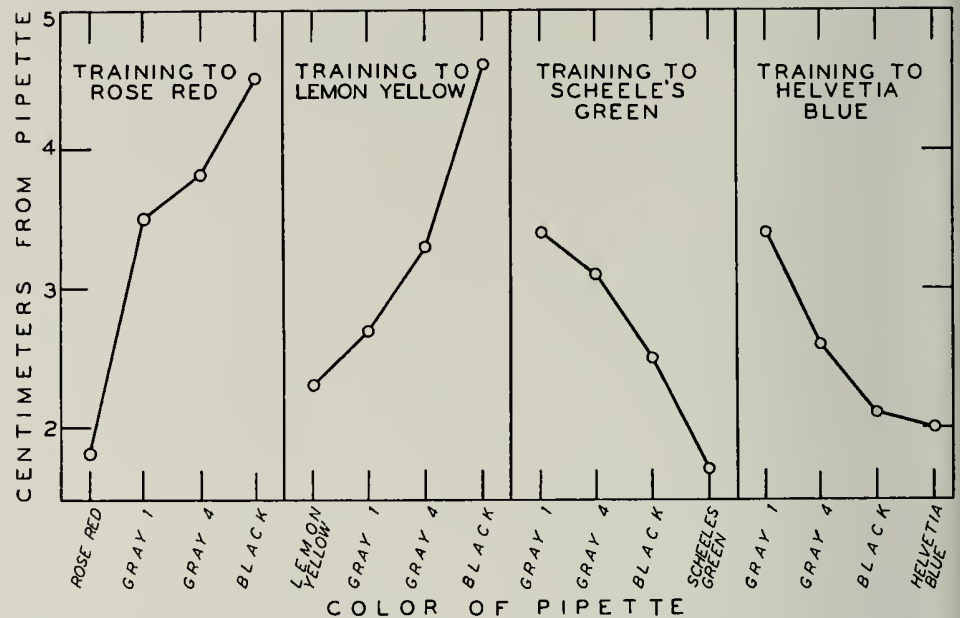

Fig. 7. - Responses of trained bass to three shades of gray and their own training color. See Table 7 .

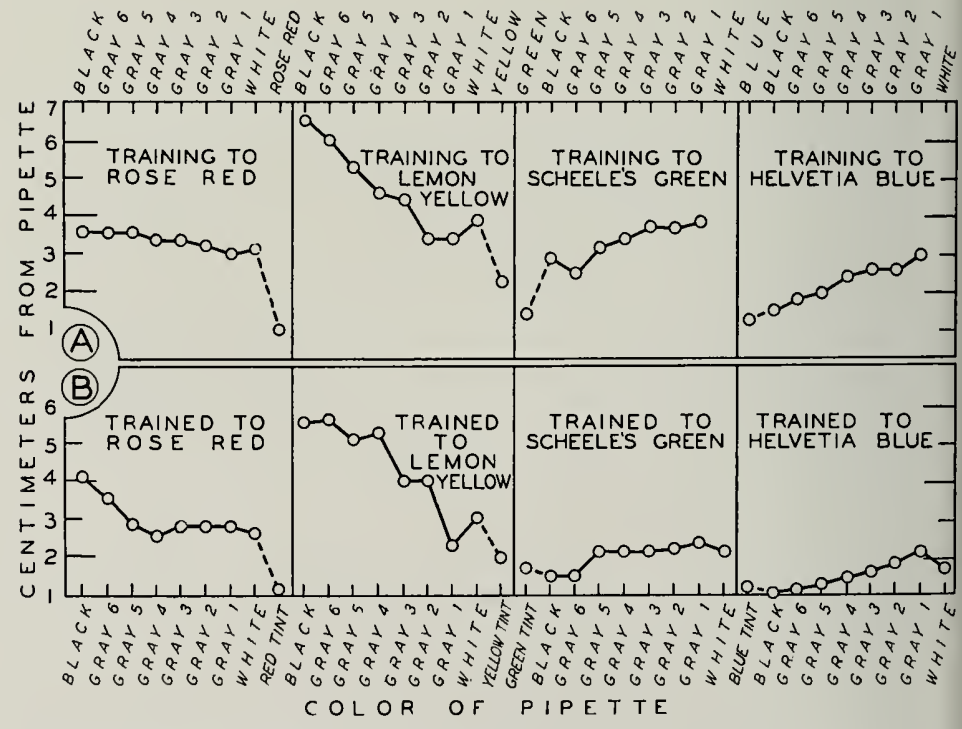

Fig. 8. - Upper, Responses of color-trained bass to their ow $n$ color and eight shades of gray. See Table 8. Lower, Responses to a strange pale tint of their own training color and to eight shades of gray. See Table 10. 
what less distinct and blue appears almost identical with the black.

All these results strongly suggest that the bass is relatively yellow-blue blind.

Bass trained to yellow were once again subjected to an intensive training for distinguishing yellow and gray 1, with the intention of ascertaining whether there was actually any color vision for yellow. A total of 100 series were carried out on the three fish. The results are indicated in Table 9. The proportional difference in the response to the two pipettes did not increase with the extra training and it was definitely below that difference between green and gray 6 for bass with considerably less training.

Response to Strange Dilute Color and Eight Shades of Gray,-In order further to establish just what part was played by intensity and what part by color the bass were shown a pale tint of the color to which they had been trained and the series of grays, white 0 to black 7 inclusive. The pale colors were light Columbia blue, pale greenish yellow, thulite pink and pale turquoise green. The fish had never before been shown these pale colors and the sudden appearance of one of these in the series of grays should have completely baffled them if they were color blind. The distinctness with which they saw the various colors should show up in the results with considerable significance in settling the question of color vision.

The bass were shown the series of grays with the color three times with neither food nor shock associated with the trials. Results, the averages of the three test trials, are shown in Table 10 , $\mathrm{A}$, and in fig. $8, \mathrm{~B}$.

The interpretation of these results is simple and clear in the instances of the fish trained to red and yellow. Here one can again draw conclusions in complete accord with those of all previous work. However, more must be considered in reading the meaning of the results in the cases of the animals trained to green and blue. Inlike the pale red and yellow pipettes, the green and blue were doubtless much lighter to the fish than the original colors and hence there must be considered the effect of the low intensity of the original training color.
If the original training Scheele's green had an equivalent intensity for the fish with gray 6 , then pale turquoise green probably would equal in intensity gray 3 or 4 . The behavior of the fish trained to Scheele's green was still positively influenced by low intensities of gray, but the fact remains that the pale green was being selected from among grays of its own intensity with the same relative precision of earlier experiments.

Table 9.- Results obtained in attempting, by intensive training, to have fish trained to yellow distinguish between lemon yellow and gray 1. Each value for individual fish represents the average number of $\mathrm{cm}$. away from the pipettes the fish remained during 10 trials.

\begin{tabular}{|c|c|c|}
\hline $\begin{array}{l}\mathrm{Fish}_{\mathrm{S}} \\
\mathrm{No} .\end{array}$ & $\begin{array}{l}\text { LEMOX } \\
\text { YELLOW }\end{array}$ & GRAY \\
\hline 20 & $\left\{\begin{array}{l}2.8 \\
5.1 \\
3.2\end{array}\right.$ & $\begin{array}{l}5.1 \\
6.8 \\
4.6\end{array}$ \\
\hline Loerage & 3.7 & 5.5 \\
\hline 24 & $\left\{\begin{array}{l}1.3 \\
1.4 \\
1.1\end{array}\right.$ & $\begin{array}{l}1.4 \\
1.5 \\
1.3\end{array}$ \\
\hline Average & 1.3 & 1.7 \\
\hline 28 & $\left\{\begin{array}{l}2.5 \\
4.2 \\
3.2 \\
2.8\end{array}\right.$ & $\begin{array}{l}3.5 \\
5.3 \\
4.2 \\
3.6\end{array}$ \\
\hline tverage & 3.2 & +1.15 \\
\hline Tolal Average & 2.7 & 3.7 \\
\hline
\end{tabular}

This is particularly noticeable with fish Nos. 21 and 29. In a similar manner the Helvetia blue-trained animals were positively and profoundly influenced by the intensity of their original training pipette. If the intensity of Helvetia blue resembled for the bass that of black 7, then light Columbia blue probably had the intensity of gray 4 or 5 , in which case these results may be favorably compared with the earlier work.

Five training trials were now given to each fish except No. 27 with the complete gray series and the pale substitute for the color to which it had been trained. These few training trials, averaged, are seen in Table $10, \mathrm{~B}$, and fig. 9. It is interesting to notice the rapidity with which the bass have learned to distinguish the new green 
from the grays of all shades, and the failure to do likewise for the yellow and blue.

Response to Spectral Color SerIEs.-The bass which now remained, Nos. 20, 21, 22, 24, 25, 26, 27, 29, 30 value taken. Nine trials were made upon the remaining fish trained to each of the four colors, with the average results shown in Table 11 and fig. 10 .

In addition to the orderly change in intensity of positive or negative response

Table 10. - The average distance in $\mathrm{cm}$. that bass remained away from a strange pale tint of the color towards which they had been trained and eight shades of gray, as shown by (A) three nontraining trials, and (B) five training trials.

\begin{tabular}{|c|c|c|c|c|c|c|c|c|c|c|}
\hline $\begin{array}{l}\text { FisH } \\
\text { No. }\end{array}$ & $\begin{array}{l}\text { TRAINING } \\
\text { COLOR }\end{array}$ & $\begin{array}{l}\text { TINT OF } \\
\text { TRAINING } \\
\text { COLOR }\end{array}$ & $\begin{array}{c}\text { WhITE } \\
0\end{array}$ & $\underset{1}{G R A Y}$ & $\underset{2}{\operatorname{Gray}}$ & $\underset{3}{\operatorname{Gray}}$ & $\begin{array}{c}\text { GRAY } \\
4\end{array}$ & $\begin{array}{c}\text { GRAY } \\
5\end{array}$ & $\underset{6}{\text { Gray }}$ & Bน.ACK \\
\hline \multicolumn{11}{|c|}{ (A) Nontraining Trials } \\
\hline $\begin{array}{c}27 \\
28 \\
24 \\
20 \\
\text { Average }\end{array}$ & $\begin{array}{l}\text { Rose red } \\
\text { Lemon yellow } \\
\text { Lemon yellow } \\
\text { Lemon yellow }\end{array}$ & $\begin{array}{l}1.2 \\
1.3 \\
1.2 \\
3.4 \\
2 .\end{array}$ & $\begin{array}{l}2.6 \\
1.9 \\
1.2 \\
6.2 \\
3.1\end{array}$ & $\begin{array}{l}2.8 \\
1.4 \\
1.1 \\
4.5 \\
2.3\end{array}$ & $\begin{array}{l}2.9 \\
1.6 \\
1.3 \\
9.1 \\
4 .\end{array}$ & $\begin{array}{l}2.9 \\
1.5 \\
1.3 \\
9.2 \\
7 .\end{array}$ & $\begin{array}{r}2.5 \\
2.1 \\
1.3 \\
12.5 \\
5.3\end{array}$ & $\begin{array}{r}2.8 \\
2.5 \\
1.3 \\
11.5 \\
5.1\end{array}$ & $\begin{array}{r}3.5 \\
3.1 \\
1.3 \\
12.8 \\
5.7\end{array}$ & $\begin{array}{r}4.1 \\
3.5 \\
1.6 \\
11.8 \\
5.6\end{array}$ \\
\hline $\begin{array}{l}21 \\
25 \\
29 \\
\text { Azerage }\end{array}$ & $\begin{array}{l}\text { Scheele's green } \\
\text { Scheele's green } \\
\text { Scheele's green }\end{array}$ & $\begin{array}{l}1.5 \\
2.4 \\
1.1 \\
1.7\end{array}$ & $\begin{array}{l}2.6 \\
2.4 \\
1.7 \\
2.2\end{array}$ & $\begin{array}{l}2.1 \\
2.9 \\
2.1 \\
2.4\end{array}$ & $\begin{array}{l}2.1 \\
3.1 \\
1.6 \\
2.3\end{array}$ & $\begin{array}{l}1.7 \\
3 . \\
1.8 \\
2.2\end{array}$ & $\begin{array}{l}1.9 \\
2.9 \\
1.7 \\
2.2\end{array}$ & $\begin{array}{l}2.1 \\
2.6 \\
1.7 \\
2.1\end{array}$ & $\begin{array}{l}1.6 \\
1.4 \\
1.6 \\
1.6\end{array}$ & $\begin{array}{l}1.8 \\
1.5 \\
1.4 \\
1.6\end{array}$ \\
\hline $\begin{array}{c}22 \\
26 \\
30 \\
\text { Average }\end{array}$ & $\begin{array}{l}\text { Helvetia blue } \\
\text { Helvetia blue } \\
\text { Helvetia blue }\end{array}$ & $\begin{array}{l}1.2 \\
1.4 \\
1.3 \\
1.3\end{array}$ & $\begin{array}{l}2 . \\
2.1 \\
1.4 \\
1.8\end{array}$ & $\begin{array}{l}2.2 \\
2.9 \\
1.3 \\
2.1\end{array}$ & $\begin{array}{l}1.8 \\
2.4 \\
1.5 \\
1.9\end{array}$ & $\begin{array}{l}1.6 \\
2.1 \\
1.4 \\
1.7\end{array}$ & $\begin{array}{l}1.4 \\
1.9 \\
1.3 \\
1.5\end{array}$ & $\begin{array}{l}1.4 \\
1.8 \\
1 . \\
1.3\end{array}$ & $\begin{array}{l}1.2 \\
1.5 \\
1.5 \\
1.2\end{array}$ & $\begin{array}{r}1.1 \\
1.4 \\
.9 \\
1.1\end{array}$ \\
\hline \multicolumn{11}{|c|}{ (B) Training Trials } \\
\hline $\begin{array}{c}28 \\
24 \\
20 \\
\text { Average }\end{array}$ & $\begin{array}{l}\text { Lemon yellow } \\
\text { Lemon yellow } \\
\text { Lemon yellow }\end{array}$ & $\begin{array}{l}2.3 \\
1.1 \\
4.1 \\
2.5\end{array}$ & $\begin{array}{l}3.1 \\
1.4 \\
8.1 \\
7.2\end{array}$ & $\begin{array}{l}2.8 \\
1.1 \\
4.2 \\
2.7\end{array}$ & $\begin{array}{l}3 . \\
1.2 \\
7.1 \\
3.8\end{array}$ & $\begin{array}{l}3.7 \\
1.3 \\
8.5 \\
7.5\end{array}$ & $\begin{array}{l}4 . \\
1.7 \\
8.8 \\
4.8\end{array}$ & $\begin{array}{r}4.1 \\
1.4 \\
10.3 \\
5.3\end{array}$ & $\begin{array}{l}4.9 \\
1.6 \\
9.7 \\
5.4\end{array}$ & $\begin{array}{r}5.3 \\
2 . \\
11.7 \\
6.3\end{array}$ \\
\hline $\begin{array}{c}21 \\
25 \\
29 \\
\text { Average }\end{array}$ & $\begin{array}{l}\text { Scheele's green } \\
\text { Scheele's green } \\
\text { Scheele's green }\end{array}$ & $\begin{array}{l}1.9 \\
1.1 \\
1.3 \\
1.4\end{array}$ & $\begin{array}{l}4.7 \\
2.8 \\
2.7 \\
3.7\end{array}$ & $\begin{array}{l}5 . \\
3.2 \\
3.4 \\
3.9\end{array}$ & $\begin{array}{l}4.7 \\
3.4 \\
2.6 \\
3.6\end{array}$ & $\begin{array}{l}5.3 \\
2.1 \\
2.6 \\
3.3\end{array}$ & $\begin{array}{l}5.5 \\
2.3 \\
2.3 \\
3.4\end{array}$ & $\begin{array}{l}2.8 \\
1.9 \\
1.9 \\
2.2\end{array}$ & $\begin{array}{l}3.8 \\
1.7 \\
1.6 \\
2.4\end{array}$ & $\begin{array}{l}5.7 \\
1.9 \\
2.3 \\
3.3\end{array}$ \\
\hline $\begin{array}{c}22 \\
26 \\
30 \\
\text { Average }\end{array}$ & $\begin{array}{l}\text { Helvetia blue } \\
\text { Helvetia blue } \\
\text { Helvetia blue }\end{array}$ & $\begin{array}{l}1.2 \\
2.1 \\
1.1 \\
1.5\end{array}$ & $\begin{array}{l}2.5 \\
2.8 \\
2.1 \\
2.5\end{array}$ & $\begin{array}{l}2.1 \\
3 . \\
1.5 \\
2.2\end{array}$ & $\begin{array}{l}2.1 \\
3.2 \\
1.2 \\
2.2\end{array}$ & $\begin{array}{l}1.7 \\
2.4 \\
1.1 \\
1.7\end{array}$ & $\begin{array}{l}1.7 \\
2.5 \\
1.2 \\
1.8\end{array}$ & $\begin{array}{l}1.3 \\
2.4 \\
1.3 \\
1.7\end{array}$ & $\begin{array}{l}1.2 \\
2.4 \\
1.1 \\
1.6\end{array}$ & $\begin{array}{r}1.1 \\
1.6 \\
.9 \\
1.2\end{array}$ \\
\hline
\end{tabular}

and $31^{3}$, were now subjected to the final experiment. The fish were shown the four colors to which they had been originally trained - rose red, lemon yellow, Scheele's green and Helvetia blue. They were fed three times (four mosquito larvae each time) from their respective feeding colors and shocked an equal number of times to each of the other three colors. Immediately thereupon they were shown in order 28 colors of the spectrum ranging from red to violet. The preparation of the colored rods used here has already been described. They had never before been shown to the bass. For some of the trials the order in which the rods were shown was from red to violet and for the remainder the order was reversed. The distance away from the colored rod at the end of three seconds was the

\footnotetext{
3 Bass No. 31 was brought in and trained to take the place of those red-trained bass, Nos. 19 and 23, that were place
}

of the fish to gradually changing wave length, the similarity between green and blue shows up with diagrammatic clarity, and there is a similarity of response between reds and violets, the last of which are a totally new color for the fish during the course of this experimentation. And finally, there are seen differential responses to different wave lengths of light which cannot be explained by response to intensity solely, in view of the other results that have been obtained. An illustration of this last is seen in the responses of the red and yellow-trained fishes to red and yellow (roughly of the same brightness to bass) and to yellow and green (of greatly different intensities to bass).

\section{INTERPRETATION OF THE RESPONSES}

The rate of learning of the young bass that have been used in the experiments has varied somewhat, depending, in 
true for red. Green stood second in this respect, then came yellow and finally blue.

Vision of the bass through the surface film of the water was remarkably acute. During the experiments the pipette was always quickly lifted above the rim of the pan and immersed. It was astounding to notice the response of the trained

Table 11. - The responses of bass trained to colors, to a series of colored rods. Each record is the average number of $\mathrm{cm}$. away from a colored rod that a fish remained during nine nontraining trials.

\begin{tabular}{|c|c|c|c|c|}
\hline & \multicolumn{4}{|c|}{ Trained To } \\
\hline & Rose & Lemon & Scheele's & $\begin{array}{c}\text { Helvetia } \\
\text { Blue }\end{array}$ \\
\hline Spectrum red & 1.92 & 3.56 & 4.42 & 3.68 \\
\hline Scarlet red & 2.4 & 3.12 & 4.56 & 3.54 \\
\hline Scarlet & 2.56 & 2.92 & 4.59 & 3.49 \\
\hline Grenadine red & 2.61 & 3.12 & 5.1 & 3,31 \\
\hline Flame scarlet & 2.76 & 2.89 & 4.55 & 3.86 \\
\hline Orange chrome & 3.02 & 2.68 & 4.75 & 3.51 \\
\hline Cadmium orange & 2.92 & 2.81 & 4.25 & 3.66 \\
\hline Orange & 2.83 & 2.29 & 4.38 & 3.54 \\
\hline Cadmium yellow & 2.98 & 1.93 & 3.94 & 3.52 \\
\hline Light cadmium & 3.04 & 2.06 & 3.67 & 3,24 \\
\hline Lemon chrome & 3.32 & 1.77 & 4.04 & 2.94 \\
\hline Lemon yellow & 3.19 & 1.79 & 3.8 & 2.98 \\
\hline Greenish yellow & 3.21 & 1.8 & 3.61 & 2.8 \\
\hline Bright green-yellow & 3.62 & 1.93 & 3.19 & 2.45 \\
\hline Neva green & 3.5 & 2.11 & 2.47 & 2.07 \\
\hline Emerald green & 3.59 & 2.41 & 1.72 & 1.85 \\
\hline Vivid green & 3.56 & 2.59 & 1.76 & 1.48 \\
\hline Skobeloff green & 3.69 & 2.9 & 1.53 & 1.53 \\
\hline Benzol green & 3.74 & 2.92 & 1.83 & 1.6 \\
\hline Italian blue & 3.56 & 3.1 & 1.75 & 1.47 \\
\hline Cerulean blue & 3.88 & 2.87 & 1.76 & 1.54 \\
\hline Methyl blue & 4 & 3.18 & 1.78 & 1.35 \\
\hline Spectrım blue & 3.87 & 3.17 & 1.89 & 1.29 \\
\hline Bradley's blue & 3.6 & 3,07 & 1.82 & 1.22 \\
\hline Phenyl blue & 3,34 & 2.81 & 2.06 & 1.41 \\
\hline Blue-violet & 2.76 & 2.94 & 2.66 & 1.93 \\
\hline Bluish violet & 2.1 & 2.74 & 4. & 3.32 \\
\hline Spectrum violet & 1.85 & 2.56 & 4.2 & 3.59 \\
\hline
\end{tabular}

fish, either positively or negatively, to a pipette at almost the instant it was lifted above the rim of the pan and long before it reached the surface of the water. With an accuracy of vision of this degree through the surface of the water it is quite understandable that bass are exceedingly adept at catching flies and other insects in the air.

As to which plays the more important role in the life of the bass, color or brightness, there is much to be considered. While casting about in search of why red might be such a distinctive color to the fish, solutions of variously colored dyes had been used in order to find some color filter which would cause the spectral colors to appear to the human eye just as the results of this research had indicated them to appear to fish. The requirements of the filter were that it would cause yellow and white to appear very closely alike, green and red must be quite distinctive colors with red a little the more so, and finally blue must appear an intermedia te between a very dark gray and green. These requirements were satisfied with a yellowish filter. After arriving at this conclusion, the work of Schnurmann (1920) and a review of it (Warner 1931) were discovered. Schnurmann concluded upon the basis of chromatophore response in Phoxinus that vision of this fish could be much like that of a colorblind human being viewing through a pair of yellow-tinted spectacles. In the eye of the light-adapted fish there is a yellow filter in the form of a yellowish retinal pigment which migrates outwards to cover to some extent the sensory elements of the eye. This pigment absorbs the shorter wave lengths much more than the longer ones. My own results indicate that the vision of light-adapted bass would more closely resemble that of a human being with perfectly normal color vision, looking through a pair of yellowish glasses. In looking at the spectral colors through such a yellow filter it is interesting in the light of the results obtained upon the bass to note that yellows and white have about the same yellowish tint; that in passing from greens to blues both look greenish but the greens appear to grow darker and darker until the deep blues have become much like black. The behavior of bass to the colors of the spectrum, fig. 10 , is in itself another argument in favor of color vision, for, were there merely a decrease in the luminosity of colors as they viewed shorter wave lengths, then this would probably be an orderly one rather than one which is to be expected in the light of the properties of colors as such, with the intervention of a yellowish screen. It is thus seen that without knowledge of the absorption spectrum of the yellow pigment of the eyes of bass it is impossible to determine the quantitative fractional parts that color and intensity play in responses of lightadapted bass, but if we may judge from reactions to red, color when clearly seen is more prominent than intensity.

The response of trained bass to the 
28 colors of the spectrum also demonstrates a similarity of response to red and violet. Here appears to be more evidence for the actuality of the "color circle" in fishes. Bass that were trained against red reacted negatively to violet, and those that were trained towards red reacted positively to violet although

\section{SUMMARY}

Thirty-one specimens of the largemouth black bass, Aplites salmoides (Lacéèzde), have been trained to respond positively to pipettes of one color and to give negative responses to pipettes of other colors. They have been trained positively to one of four

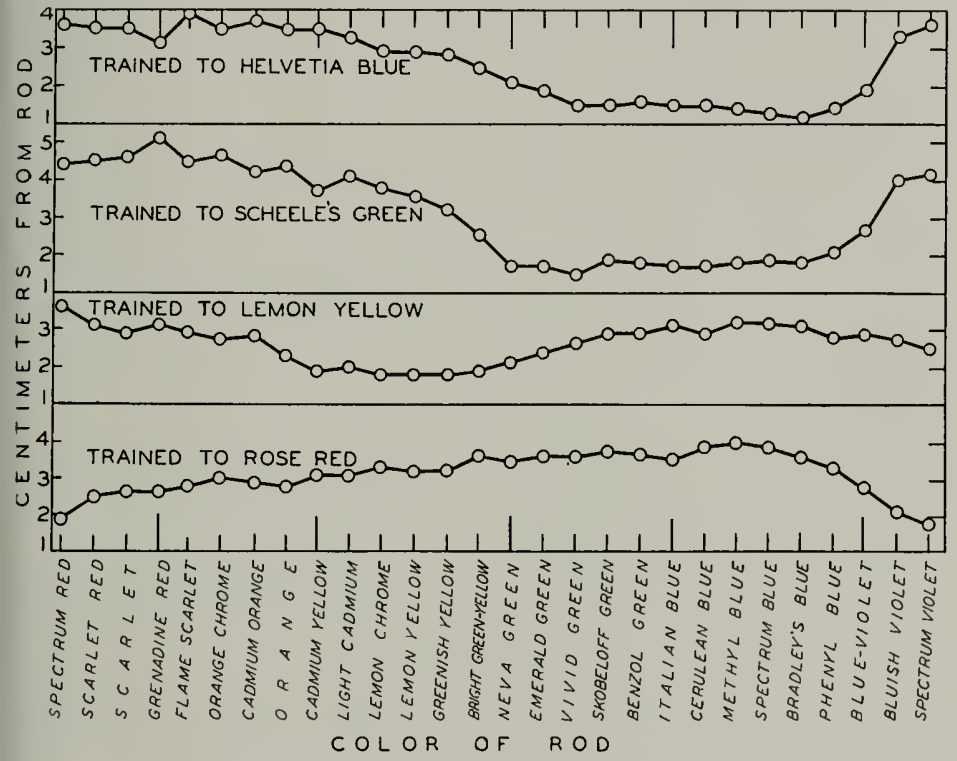

Fig. 10.-Average responses of color-trained bass to a spectral series of colors. See Table 11 .

violet had never before been shown to the fish. This response also indicates that the yellow pigment of the eye does not absorb violet very strongly.

Disregarding for the moment the similarity between certain grays and certain colors, it is seen that, excluding violet, the difference between colors for light-adapted bass is a function of the difference in wave length. Colors that differ most in wave length are most strongly contrasted by training. As to how far this is a response to differing brightnesses brought about by the differentially absorbing yellow pigment of the retina and how far it is due to changing in color value proper, remains for further research. colors-red, yellow, green, blue-in the instances of different fish, and negatively to the remaining three colors. All experiments were carried out upon lightadapted bass kept upon a white background in a light intensity of 12 to 20 foot-candles.

Freshly collected bass which have been in the laboratory no more than two days, and fed Daphnia during that time, are most attracted by red, then in order of decreasing attraction of the colors used come yellow, white, green, blue and black.

For pipettes which are distinctly different from one another for the bass, learning is accomplished in five to 10 trials, but when the difference is less the 
training must be somewhat longer to produce a definitely modified behavior.

Both color and intensity play parts in the responses of the bass to objects. There has not yet been given a sufficient amount of training to have them respond solely to color.

Red appears to be the outstanding color, as such, in the responses of the bass. This color is easily and readily selected from everything else, with the exception of violet.

Bass learn very readily to respond preferentially to yellow as contrasted with red, green and blue, but there is great difficulty experienced in distinguishing between yellow and very light gray.

Green and blue are colors towards which the bass learned to respond positively with the most difficulty. Although these colors were readily distinguished from red and yellow, yet they were distinguished from one another much more poorly. Blue, dark grays and black were distinguished from one another with little accuracy, and greens were more confused with blues than with the grays. Blue would therefore appear to occupy a tinted shade intermediate between green and dark gray.

Bass trained to red and yellow responded more positively to the lighter of the grays, while those trained to green and blue responded more positively to the darker grays. This was interpreted to signify that reds and yellows are colors of high intensity to the fish while greens and blues are colors of low intensities.

The gray most nearly corresponding in apparent brightness to each of the training pipettes was determined, and from the relative differences in response to these pairs of pipettes it was determined that the order of distinctness from gray of the four colors for the bass was first, red, then in order came green, yellow and blue. The evidence indicates that bass are relatively yellowblue blind.

The conclusion of Schnurmann (1920) that light-adapted fish respond in vision as if they were seeing through a yellowish screen has been confirmed. The re- sults of this experiment indicate that the fish are able to distinguish among colors in about the same manner as would a human being with perfectly normal color vision looking through a yellowish filter.

The similarity of the reds and violets is further evidence in favor of similarity of color vision of man and bass. It further suggests that the yellow screen of the eye of the fish does not absorb violet very strongly.

The responses of bass to 28 colors of the visible spectrum not only demonstrate a quite definite specificity to a particular color, but bring out strongly the degrees of similarity and dissimilarity of colors differing to a greater or lesser extent in wave length. In general, and excepting the violets, the degree of difference of different colors to bass is a function of the difference in wave length.

\section{BIBLIOGRAPHY}

Bauer, V.

1910 Ueber das Farbenunterscheidungsvermögen der Fische. Archiv für die gesammte Physiologie $133(1,2,3): 7$. 26. June 18.

$1911 \mathrm{Zu}$ meinen Versuchen über das Farbenunterscheidungsvermögen der $\mathrm{Fi}$ sche. Archiv für die gesammte Physiologie 137(11-12):622-6. Jan. 26.

Burkamp, W.

1923 Versuche über das Farbenwiedererkennen der Fische. Zeitschrift für Psychologie und Physiologie der Sinnesorgane, Abteilung $11,55: 133-70.2$ figs.

Connolly, C. J.

1925 Adaptive changes in shade and color of Fundulus. Biol. Bul. 48(1):56-77. Jan.

Frisch, K, von

1912 Sind die Fische Farbenblind? Zoologische Jahrbücher; Abteilung für allgemeine Zoologie und Physiologie der Tiere 33(1):107-26. 2 fig. Nov. 9.

1913 Weitere Untersuchungen über den Farbensinn der Fische. Zoologische Jahrbucher; Abteilung für allgemeine Zoologie und Physiologie der Tiere 34(1):43-68. 5 figs. Dec. 30 .

Graber, V.

1884 Grundlinien zur Erforschung des Helligkeits und Farbensinnes der Tiere. Prag. Tempsky. 322 pp. (Cited from Warner 1931).

1885 Uber die Helligkeits und Farbenempfindlichkeit einiger Meertiere. Sitzungsberichte der Akademie der Wis- 
senschaften- Mathematischen- Naturwissenschlaftliche Klasse, Abteilung I, $91: 129-50$. Wien. (Cited from Warner 1931).

\section{Haempel, $O$. and W. Kolmer}

1914 Ein Beitrag zur Helligkeits und Farbenanpassung bei Fischen. Biologisches Centralblatt $\mathbf{3 4}(7): 450-8$. July 20.

\section{Hafen, G.}

1935 Zur Psychologie der Dressurversuche. Zeitschrift für vergleichende Physiologie 22(2):192-220. 5 figs. June 13.

Hess, C.

1910 Über den angeblichen Nachweis von Farbensinn bei Fischen. Archiv für die gesammte Physiologie 134 $(1,2)$ : 1-14. Aug. 15.

1911 Experimentelle Untersuchungen zur vergleichenden Physiologie des Gesichtssinnes Archiv für die gesammte Physiologie $142(9,10,11,12): \$ 05-46$. 5 figs. Oct. 30 .

1913 Untersuchungen zür Frage nach dem Vorkommen von Farbensinn bei Fischen. Zoologische Jahrbucher; Abteilung fur allgemeine Zoologie und Physiologie der Tiere 31(t):629-46. 1 fig. Apr. 1.

1914 Untersuchungen zur Physiologie des Gesichtssinnes der Fische. Zeitschrift fur Biologie $63 \mid 45$ n.s. $: 245-74 . \quad 14$ figs. Feb, 6.

\section{Hineline, G. M. (White)}

1927 Color vision in the mud-minnow. Jour. Exp. Zool. 47(1):85-94. 3 charts. Feb.

Mast, S. O.

1916 Changes in shape, color and pattern in fishes and their bearing on the problems of adaptation and behavior, with especial reference to the flounders, Paralichthys and Ancylopsetta. Bul. U. S. Bur. Fisheries 34:173-238. Doc. 821.3 figs., 37 pls. Apr. 10.

Reeves, C. D.

1919 Discrimination of light of different wave lengths by fish. Behav. Mlonog. 4(3). Serial No, 19.106 pp., 17 figs. May 23.
Reighard, J. E.

1908 An experimental field study of warning coloration in coral reef fishes. Carnegie Inst. of Wash. Pubs., No. 103. Papers from the Tortugas Lab, 2: 257-325. 1 fig. 5 pls.

Ridgway, $\mathrm{R}$.

1912 Color standards and color nomenclature. Published by author. $\$ 3$ pp., 53 colored pls., 1115 named colors. Wash., D. C.

\section{Schiemenz, F.}

1924 Über den Farbensinn der Fische. Zeitschrift fur vergleichende Physiologie 1(1,2):175-220. 2 figs. Apr. 17.

Schnurmann, F.

1920 Untersuchungen an Elritzen uber Farbenwechsel und Lichtsinn der Fische. Zeitschrift fur Biologie 71[53 n.s. $]$ (2):69-98. May 28.

\section{Sumner, F. B.}

1911 The adjustment of flatfishes to various backgrounds: A study of adaptive color change. Jour. Exp. Zool. $10(4): 109-506.13$ pls. May.

\section{Warner, L. H.}

1931 The problem of color vision in fishes. Quart. Rev. Biol. 6(3):329-48. + figs. Sept.

Washburn, M. and I. M. Bentley

1906 The establishment of an association involving color discrimination in the creek chub, Semotilus atromaculatus. Jour. Comp. Neurol. 16(2):113-25. Mar.

White, G. H.

1919 Association and color discrimination in mud minnows and sticklebacks. Jour. Exp. Zool. 27(4):443-98. 10 figs. Feb.

Wolff, $\mathrm{H}$.

1926 Das Farbenunterscheidungsvermögen der Ellritze. Zeitschrift für vergleichende Physiologie 3(3):279-329. 2S figs. Dec. 19.

Zolotnitsky, $\mathrm{N}$.

1901 Les poisson distingent-ils les couleur? Archives de Zoologie Expérimentale et Générale, ser. 3,9(1):1-5 